Article

\title{
Isocorydine Derivatives and Their Anticancer Activities
}

\author{
Mei Zhong ${ }^{1,2}$, Yanjuan Liu ${ }^{1,2}$, Junxi Liu ${ }^{1}{ }^{*}$, Duolong Di ${ }^{1}$, Mengrou Xu ${ }^{3}$, Yaya Yang ${ }^{3}$, \\ Wenguang $\mathrm{Li}^{3}$, Yali Chen ${ }^{3}$ and Jinxia Liu ${ }^{4}$
}

1 Key Laboratory of Chemistry of Northwestern Plant Resources and Key Laboratory for Natural Medicine of Gansu Province, Lanzhou Institute of Chemical Physics, Chinese Academy of Sciences, Lanzhou 730000, China; E-Mails: zhongmei@licp.cas.cn (M.Z.); liuyanjuan09@163.com (Y.L.); did1@licp.cas.cn (D.D.)

2 Graduate University of the Chinese Academy of Sciences, Beijing 100049, China

3 Gansu Key Laboratory of Preclinical Study for New Drugs, Institute of Pharmacology, School of Basic Medical Science, Lanzhou University, Lanzhou 730000, China; E-Mails: xmr1991@126.com (M.X.); yangmegan2011@hotmail.com (Y.Y.); liwg@1zu.edu.cn (W.L.); cheny12013@licp.cas.cn (Y.C.)

4 Institute of Biology, Gansu Academy of Sciences, Lanzhou 730000, China; E-Mail: Liujinx0168@163.com

* Author to whom correspondence should be addressed; E-Mail: liujx@licp.cas.cn; Tel.: +86-931-4968-212; Fax: +86-931-8277-088.

Received: 5 June 2014; in revised form: 13 July 2014 / Accepted: 22 July 2014 /

Published: 12 August 2014

\begin{abstract}
In order to improve the anticancer activity of isocorydine (ICD), ten isocorydine derivatives were prepared through chemical structure modifications, and their in vitro and in vivo activities were experimentally investigated. 8-Amino-isocorydine (8) and 6a,7-dihydrogen-isocorydione (10) could inhibit the growth of human lung (A549), gastric (SGC7901) and liver (HepG2) cancer cell lines in vitro. Isocorydione (2) could inhibit the tumor growth of murine sarcoma $\mathrm{S}_{180}$-bearing mice, and 8-acetamino-isocorydine (11), a pro-drug of 8-amino-isocorydine (8), which is instable in water solution at room temperature, had a good inhibitory effect on murine hepatoma $\mathrm{H}_{22}$-induced tumors. The results suggested that the isocorydine structural modifications at C-8 could significantly improve the biological activity of this alkaloid, indicating its suitability as a lead compound in the development of an effective anticancer agent.
\end{abstract}


Keywords: aporphine alkaloids; isocorydine; synthesis; anticancer activity

\section{Introduction}

Aporphine alkaloids belong to benzylisoquinoline alkaloids, existing in 20 families and more than 100 genera of plants. These alkaloids share the common characteristic of a tetracyclic skeleton, albeit with different substituents. The aporphine template is associated with a wide range of biological activities, such as acting as a dopaminergic agent, anti-platelet activities, anti-oxidative properties and cytotoxic activities. Because of their attractive biological activities, many studies have focused on the potential of aporphinoid alkaloids in drug development, and the anticancer activity of these compounds has become a hot pharmaceutical research area in recent years [1-6]. Isocorydine (1), an aporphine alkaloid, is widely present in many plants, including Dicranostigma leptopodum (Maxim) Fedde, which is mainly distributed in the northwest of China. In our continued investigation to find antitumor compounds from natural resources, we found that isocorydine was abundant in this plant $[7,8]$. Recent research has demonstrated that isocorydine not only inhibits cell proliferation in hepatocellular carcinoma cell lines by inducing G2/M cell cycle arrest and apoptosis, but also targets the drug-resistant cellular side population (or cancer stem cells) through inducing PDCD4-related apoptosis. Furthermore, isocorydine could selectively reduce the size and weight of the side population cell-induced tumor masses in nude mice, which suggested that isocorydine is a potential therapeutic drug for targeting the side population cancer cells of hepatocellular carcinoma [9,10]. Cancer stem cells show self-renewal properties and chemoresistance to the majority of anticancer agents, which is a challenge in clinical chemotherapy. Isocorydine could not only significantly reduce the percentage of $\mathrm{CD}_{133^{+}}$and EpCAM-expressing cells, two types of cancer stem cells, but also could suppress the ability of primary liver carcinoma $\mathrm{PLC} / \mathrm{PRF} / 5 \mathrm{CD} 133^{+}$cells to form hepatospheres and tumor-like spheres in vitro [9-11]. However, isocorydine shows only intermediate antitumor ability, and the effective dosage could reach up $200 \mu \mathrm{M}$, which is a relatively high dosage for clinical treatment [10]. In order to reduce the dosage of isocorydine needed to achieve an effective outcome and improve the anticancer activity, we used chemical modification and structure transformation to obtain a series of isocorydine derivatives. We here report the results of bioactivity investigations and summarize the primary structure-activity relationships of isocorydine derivatives as antitumor agents.

\section{Results and Discussion}

\subsection{Chemistry}

The synthetic routes of isocorydine derivatives are shown in Scheme 1. Modifications at the C-8 position in the D ring of isocorydine were the focus of our work. Ten aporphine compounds were obtained through structural modifications of isocorydine. The starting material, isocorydine (1) as a colorless crystal, was isolated from D. leptopodum (Maxim) Fedde using column chromatography on a silica gel in our laboratory. Its ${ }^{1} \mathrm{H},{ }^{13} \mathrm{C}$ nuclear magnetic resonance (NMR) spectra and its X-ray crystal structure (Figure 1) were consistent with data reported in former literature [12,13]. While isolating the 
chemical constituents of D. leptopodum (Maxim) Fedde, a small amount of isocorydione (2), which has a p-benzoquinonyl structure, was also isolated. However, the low content of $\mathbf{2}$ in the plant limited the ability to screen its activity in the pharmacology experiments. Chia et al. successfully obtained norfissilandione, which retained the p-benzoquinonyl segment through fissoldine oxidized by Fremy's radical, which is a mild oxidant and can transform the phenolic hydroxyl segment to p-benzoquinonyl [14]. Using this method, Compound $\mathbf{2}$ was synthesized through oxidization of 1 by Fremy's radical, and Compounds 3, 4 and 5 were also isolated as by-products of this reaction. The oxidization mechanism of isocorydine involved four molecular of Fremy's radicals, which resulted in isocorydine losing relevant hydrogen atoms in its chemical structure. The hydrogen atom located at C-8 possesses high chemical reactivity and is easily lost. Considering the low polarity of 2, Compound $\mathbf{6}$ was prepared through the nucleophilic addition reaction between hydroxylamine hydrochloride with the carbonyl group at position C-8 of 2 . Nitration of isocorydine at $-30{ }^{\circ} \mathrm{C}$ generated 7, which contained a nitro-group at C-8. The low temperature was necessary in this experiment, as oxidation of the phenolic hydroxyl in isocorydine can easily occur by reaction with nitric acid. Due to the steric hindrance of the methoxyl group at C-2, no nitro-substituted product was obtained at C-3. In order to conduct a relatively clean reaction involving green chemistry, 7 was reduced under hydrogen pressure at $0.3 \mathrm{MPa}$ and was catalyzed by palladium/carbon hydrogenation catalyst $(10 \%)$ to obtain $\mathbf{8}$, which is a brown amorphous powder. The reduction reaction required neutral mild conditions, for Compound $\mathbf{8}$ was not stable at room temperature and could be easily degraded. Even the weak oxidant sodium nitrite could oxidize $\mathbf{8}$ to 10 at $0{ }^{\circ} \mathrm{C}$. Compound $\mathbf{9}$ was obtained through electrophilic substitution between isocorydine and a chloride atom of N-chlorosuccinimide, a typical chloridizing reagent.

Figure 1. X-ray crystal structures of $\mathbf{1}$ and $\mathbf{2}$. The molecular planarity of $\mathbf{2}$ was superior to that of 1 due to the double bond of C-6a and C-7, which could conjugate with benzene rings in $\mathbf{2}$ and reduce the dihedral angle of biphenyl to zero. The chirality of C-6a in $\mathbf{1}$ resulted in non-rigid conformation of the ring of $\mathrm{B}$ and $\mathrm{C}$.

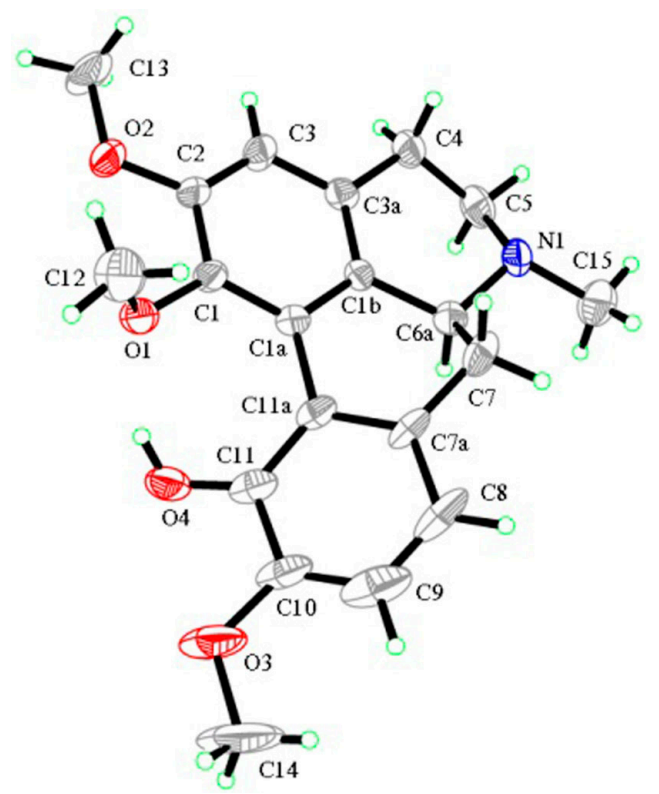

1

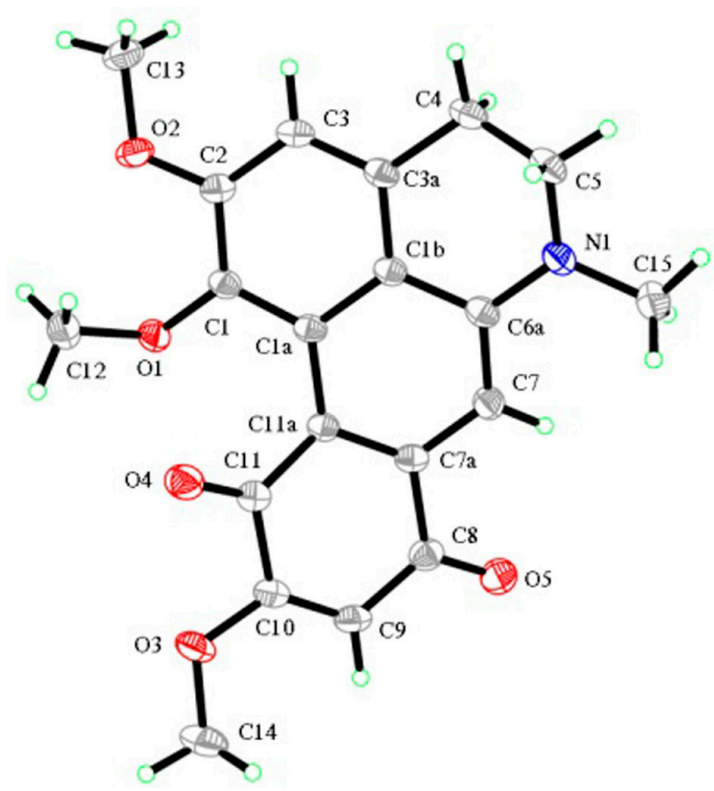

2 
Scheme 1. The synthetic route of isocorydine derivatives. Reagents and conditions: (A) $\mathrm{ON}\left(\mathrm{SO}_{3} \mathrm{~K}\right)_{2} / \mathrm{H}_{2} \mathrm{O} / \mathrm{Na}_{2} \mathrm{HPO}_{4}, 25^{\circ} \mathrm{C}$, stir, $24.0 \mathrm{~h}$; (B) $\mathrm{NH}_{2} \mathrm{OH} \cdot \mathrm{HCl} / \mathrm{EtOH}, 80{ }^{\circ} \mathrm{C}$, reflux, $1.5 \mathrm{~h}$; (C) $\mathrm{HNO}_{3} / \mathrm{H}_{2} \mathrm{SO}_{4} / \mathrm{CHCl}_{3} / \mathrm{CH}_{2} \mathrm{Cl}_{2},-30{ }^{\circ} \mathrm{C}$, stir, $1.5 \mathrm{~h}$; (D) $0.3 \mathrm{MPa} \mathrm{H}, \mathrm{Pd} / \mathrm{C}, \mathrm{EtOH}$, $25^{\circ} \mathrm{C}$, stir, $2.5 \mathrm{~h}$; (E) NCS/CH${ }_{3} \mathrm{COOH}, 7{ }^{\circ} \mathrm{C}$, stir, $2.0 \mathrm{~h}$; (F) $\mathrm{NaNO}_{2} / \mathrm{HCl}, 0{ }^{\circ} \mathrm{C}$, stir, $1.0 \mathrm{~h}$; (G) $\mathrm{CH}_{3} \mathrm{COCl}$, stir, $2.0 \mathrm{~h}$.

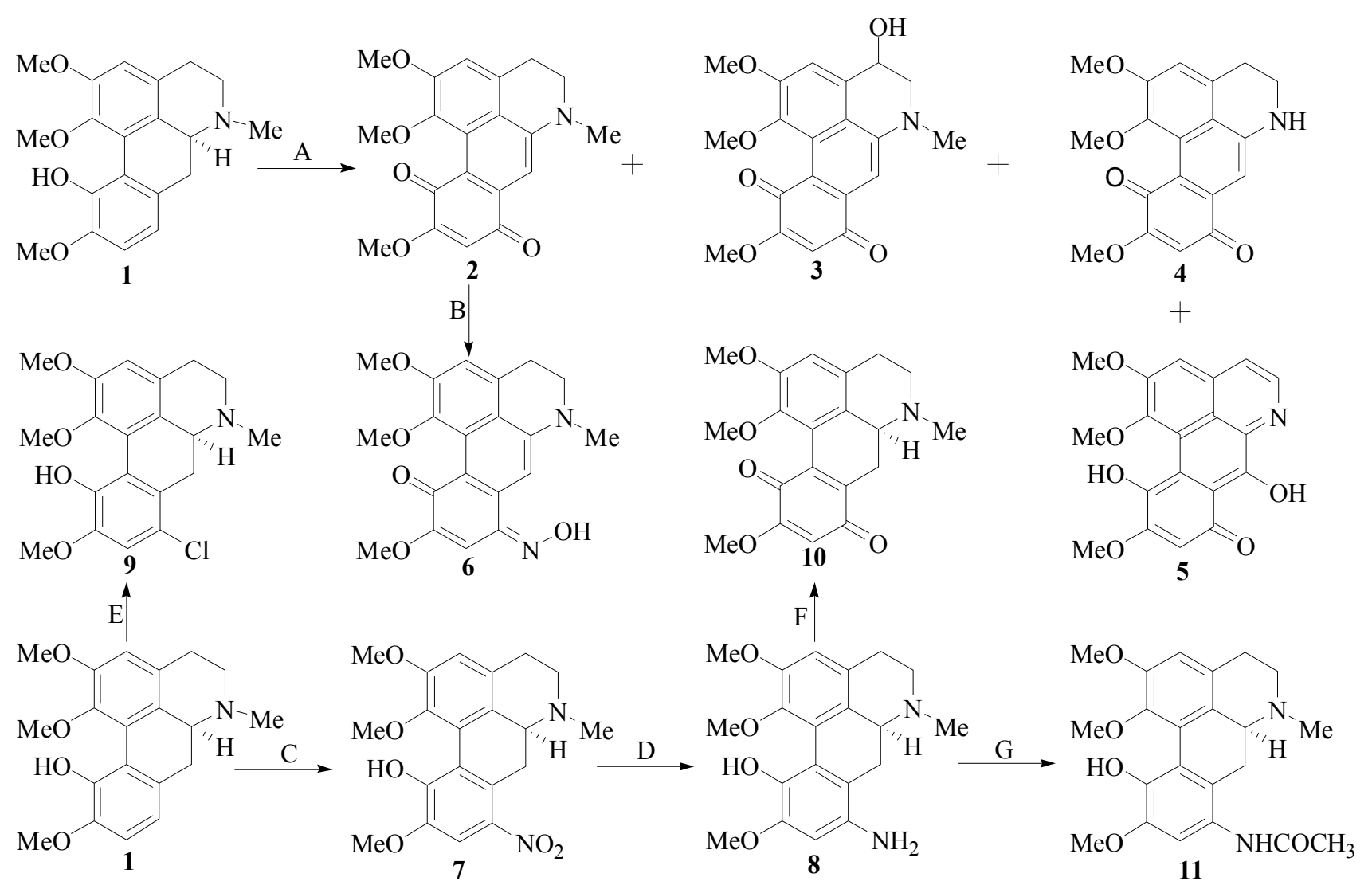

During mice biological activity experiments, we discovered that the color of the water solution of $\mathbf{8}$ became darker over time, suggesting that $\mathbf{8}$ was not stable in water solution. Therefore, the degrading mechanism of $\mathbf{8}$ was further investigated using the liquid chromatography-mass spectrometry (LC-MS)-trap method. In comparing the chromatogram of $\mathbf{8}$ at different time points, such as between the time of fresh preparation and after $48 \mathrm{~h}$ of standing at room temperature (Figure 2), we found that $60 \%$ of 8 was degraded and transformed into two major chemical structures (b and $\mathrm{c}$ in Figure 2 and Scheme 2). As shown in the total ion chromatogram in Figure 2B, the mass spectra peaks of the two major degradation products were detected at a mass-to-charge ratio $(\mathrm{m} / \mathrm{z})$ of $355.2[\mathrm{M}+\mathrm{H}]^{+}$ (Compound $\mathrm{b}$ in Figure 2D) and $356.2[\mathrm{M}+\mathrm{H}]^{+}$(Compound $\mathrm{c}$ in Figure 2E) in a positive detection manner. The $\mathrm{m} / \mathrm{z}$ of the two major degradation products was almost identical with that of Compound 8 (a: $m / z 357.2[\mathrm{M}+\mathrm{H}]^{+}$in Figure $2 \mathrm{C}$ ), which indicated that the degraded molecules lost only one or two hydrogen atoms while retaining the complete molecular skeleton. The degradation mechanism was elucidated and is shown in Scheme 2. The p-aminophenol segment in the structure of $\mathbf{8}$ would be easily oxidized in water solution under the presence of hydrogen ion. Therefore, the introduced active segment should be protected to increase the stabilization of Compound $\mathbf{8}$. To achieve this, based on the pro-drug theory, Compound $\mathbf{1 1}$ was synthesized through acetylating $\mathbf{8}$ with acetyl chlorine, which 
could not only protect the p-aminophenol segment, but could also be hydrolyzed by enzymolysis and transform to the original compound in vivo. Thus, the stabilization problem was resolved.

Figure 2. Evaluation of the instability of 8-amino-isocorydine (8) using the HPLC-UV-MS method. (A) Representative chromatogram of the degradation products of 8-amino-isocorydine (8) in water solution at room temperature over 48 h. (a: Compound 8 ; $\mathrm{b}$ and $\mathrm{c}$ are the main degradation products.). The mobile phase conditions were as follows: UV detector set at $270 \mathrm{~nm}$, a SinoCrom ODS-BP C18 column $(4.6 \times 250 \mathrm{~mm}, 5 \mu \mathrm{m})$ was used with the mobile phase consisting of $\mathrm{MeOH}$ : water (65:35, using aqua ammonia adjusted $\mathrm{pH}$ at 7.2) at a flow rate of $1.0 \mathrm{~mL} / \mathrm{min}$. The column temperature was maintained at $25^{\circ} \mathrm{C}$; (B) Total ion chromatogram (TIC) of $\mathbf{8}$ by the LC-MSD-trap method. MS detection was conducted by ESI and operated in positive mode; (C) MS spectra tracked for a, $\mathrm{m} / \mathrm{z}=357.2$ at $6.1 \mathrm{~min}$; (D) MS spectra tracked for b, $\mathrm{m} / \mathrm{z}=355.2$ at $8.3 \mathrm{~min}$; (E) MS spectra tracked for $\mathrm{c}, m / z=357.2$ at $10.6 \mathrm{~min}$.
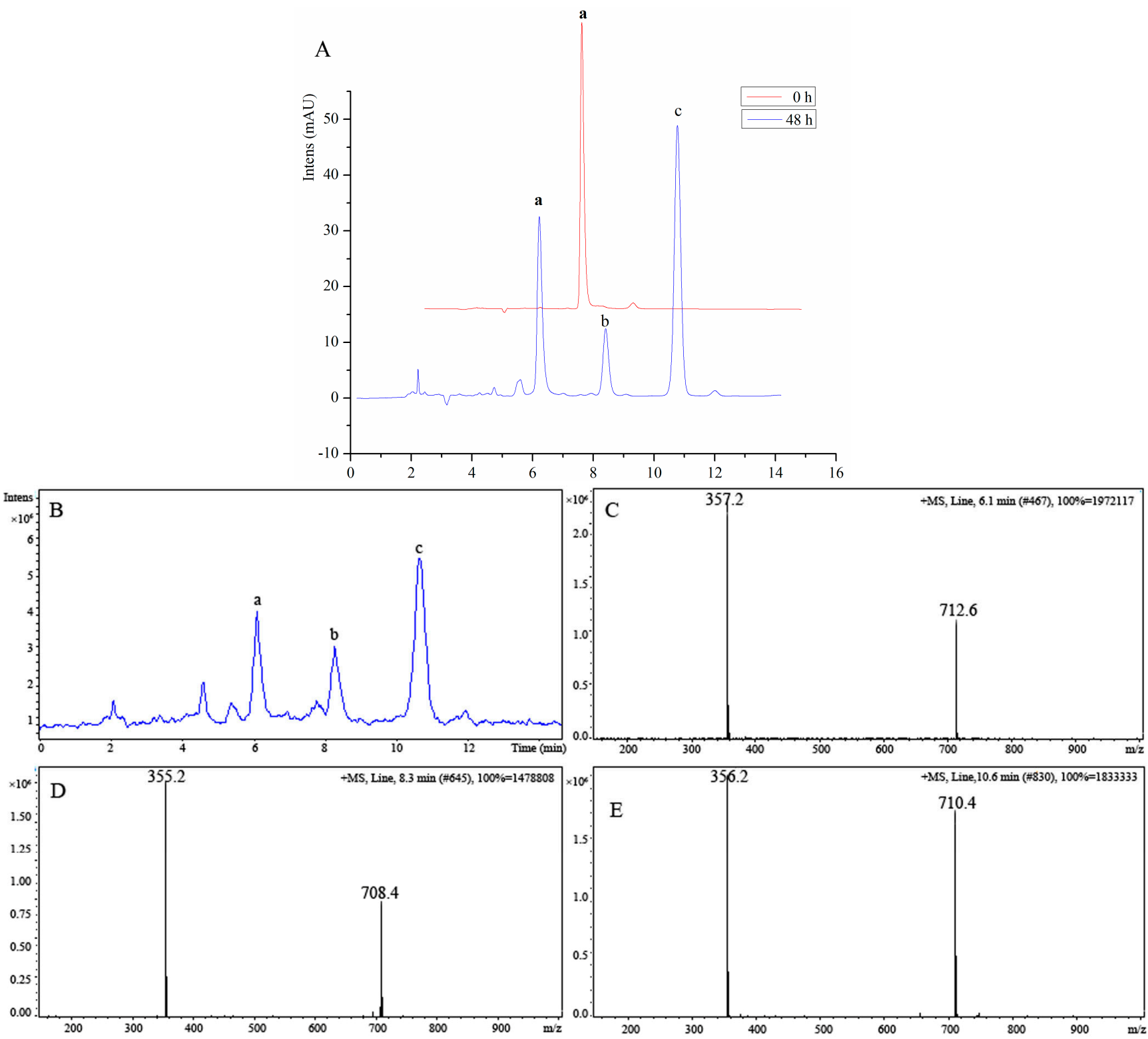
Scheme 2. The main degrade products and the degrade route of 8-amino-isocorydine $(\mathbf{8})$ in water solution at room temperature.

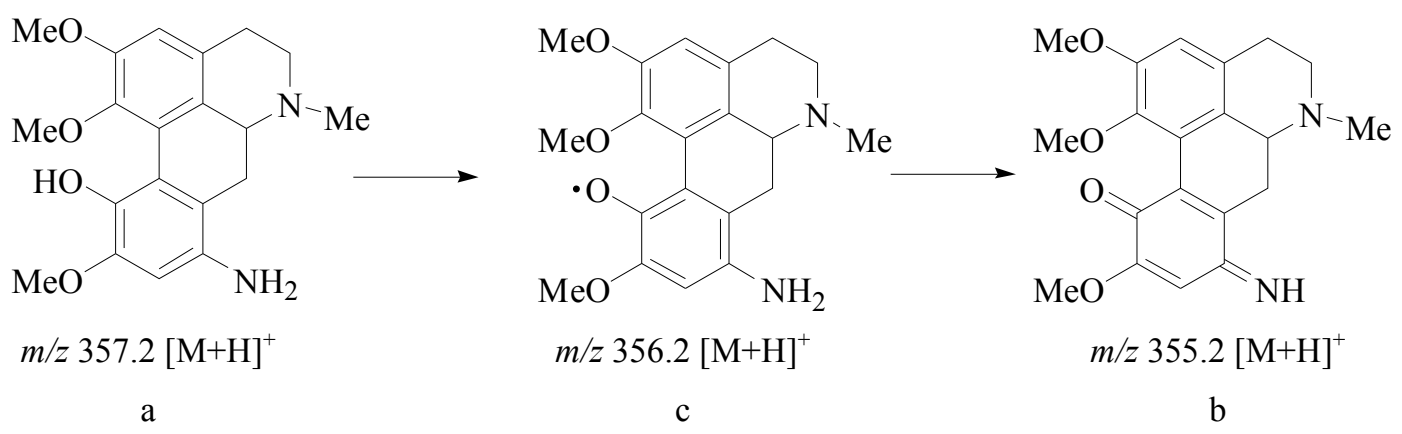

\subsection{Biological Activity}

\subsubsection{In Vitro Anticancer Activity}

Anticancer activities of the key isocorydine derivatives and reference compound cisplatin were screened by using the MTT assay in three common human cancer cell lines: liver (HepG2), lung (A549) and gastric (SGC7901) cancer cells [15]. The 50\% inhibitory concentration ( $\left.\mathrm{IC}_{50}\right)$ values of the isocorydine derivatives and positive control compound exposed for $48 \mathrm{~h}$ are listed in Table 1. Among the tested compounds, Compounds $\mathbf{8}$ and $\mathbf{1 0}$ showed relatively low $\mathrm{IC}_{50}$ values: $56.18 \mu \mathrm{M}, 7.53 \mu \mathrm{M}$ and $14.80 \mu \mathrm{M}$ for Compound 8 and $20.42 \mu \mathrm{M}, 8.59 \mu \mathrm{M}$ and $14.03 \mu \mathrm{M}$ for Compound 10 in the three cell lines, respectively. Compared to isocorydine (1), the pharmacological activities of $\mathbf{8}$ and $\mathbf{1 0}$ were improved significantly. Therefore, $\mathbf{8}$ and $\mathbf{1 0}$ were selected as potent anticancer agents for further researches in vivo. While among the isocorydine derivatives, 2 exhibited relatively weak anticancer activities against the three cell lines ( $\mathrm{IC}_{50}$ : $186.97 \mu \mathrm{M}, 197.73 \mu \mathrm{M}$ and $212.46 \mu \mathrm{M}$ ). The only difference found in the chemical structures of $\mathbf{2}$ and $\mathbf{1 0}$ was the lack of absolute configuration at C-6a, which should therefore be regarded as the key factor affecting the pharmacological activity of aporphine alkaloids.

Table 1. Anticancer activities of the key isocorydine derivatives on three common human cancer cell lines.

\begin{tabular}{cccc}
\hline \multirow{2}{*}{ Compounds } & \multicolumn{3}{c}{ Mean $\mathbf{I C}_{\mathbf{5 0}}(\boldsymbol{\mu M})$} \\
\cline { 2 - 4 } & HepG2 & $\mathbf{A 5 4 9}$ & SGC7901 \\
\hline 1 & $>200.00$ & $>200.00$ & $>200.00$ \\
2 & 186.97 & 197.73 & $>200.00$ \\
6 & 78.10 & 63.70 & 67.91 \\
7 & $>200.00$ & $>200.00$ & $>200.00$ \\
8 & 56.18 & 7.53 & 14.80 \\
9 & $>200.00$ & $>200.00$ & $>200.00$ \\
10 & 20.42 & 8.59 & 14.03 \\
11 & $>200.00$ & $>200.00$ & $>200.00$ \\
Cisplatin & 0.67 & 1.02 & 0.88 \\
\hline
\end{tabular}

Compound 6, which was obtained through further modification of 2, exhibited better anticancer activities against HepG2, A549 and SGC7901 cells $\left(\mathrm{IC}_{50}: 78.10 \mu \mathrm{M}, 63.70 \mu \mathrm{M}\right.$ and $67.91 \mu \mathrm{M}$, 
respectively) than $\mathbf{2}$. Compounds $\mathbf{7}$ and $\mathbf{9}$, which were prepared by replacing the hydrogen atom of isocorydine at C-8 with nitro and chloride, respectively, showed no inhibitory effects on the selected cancer cell lines, due to their strong hydrophobicity, which limited their effective concentrations in cells cultured in media. As expected, Compound 11, which was synthesized based on the pro-drug theory [16] to protect the p-aminophenol fragment, also did not show anticancer activity.

\subsubsection{In Vivo Anticancer Activity}

Given the relatively easy preparation and the p-benzoquinonyl pharmacophore of Compound 2, the pro-drug design and the good antitumor activity in vitro of Compound 8, Compounds $\mathbf{2}$ and $\mathbf{1 1}$ were selected for evaluation of the tumor growth inhibition in tumor-bearing mice at three different dosages (low, medium and high). The in vivo anticancer activity of $\mathbf{1 0}$ ultimately could not be evaluated, due to its poor solubility in water and low yield. The inhibitory effect of isocorydione (2) on murine sarcoma $\mathrm{S}_{180}$-bearing mice is detailed in Table 2 . The inhibitory rate and tumor weight of the treatment group were significantly different from those of the blank control group (physiological saline). The tumor inhibitory rate increased with increasing dosage (Figure S1). Although the inhibitory rate of 2 was not better than that of the positive control group treated with cyclophosphamide (CTX), the weights of mice treated with 2 were significantly $(p<0.05)$ higher than those of the CTX group.

Table 2. Inhibitory effect of isocorydione (2) on $\mathrm{S}_{180}$-bearing mice.

\begin{tabular}{ccccc}
\hline $\begin{array}{c}\text { Treatment } \\
\text { group }\end{array}$ & $\begin{array}{c}\text { Mice } \\
\text { number }\end{array}$ & $\begin{array}{c}\text { Dose } \\
(\mathbf{m g} / \mathbf{k g} / \mathbf{d})\end{array}$ & $\begin{array}{c}\text { Tumor weight } \\
\mathbf{( g ,} \text { Mean } \pm \text { SD) }\end{array}$ & $\begin{array}{c}\text { Inhibition ratio } \\
\mathbf{( \% )}\end{array}$ \\
\hline Control & 11 & - & $1.2917 \pm 0.0935$ & - \\
2 & 11 & 200 & $0.6431 \pm 0.0197 * *$ & 50.21 \\
2 & 11 & 100 & $0.7011 \pm 0.0480 *$ & 45.72 \\
2 & 11 & 50 & $0.9661 \pm 0.0720$ & 25.21 \\
CTX & 11 & 20 & $0.4645 \pm 0.0152 * *$ & 64.04 \\
\hline
\end{tabular}

vs. the control group: $* p<0.05, * * p<0.01$.

In preliminary experiments, the tumor growth inhibitory effect of $\mathbf{1 1}$ on $\mathrm{S}_{180}$-bearing mice was relatively weak (Figure S2). Therefore, the murine hepatoma $\mathrm{H}_{22}$ mouse model was selected for this investigation. The inhibitory effect of $\mathbf{1 1}$ on $\mathrm{H}_{22}$ tumors is detailed in Table 3. The inhibitory rate of the high-dose group and the medium-dose group were similar (52.71\% and $53.12 \%$, respectively); however, the tumor weight and size of the CTX group and the three dosage groups were significantly different from those of the control group (Figure 3A,B). Compared to CTX, the inhibitory effect of Compound 11 was not strong, but the mean body weight of the CTX group was significantly $(p<0.05)$ lower than those of the dosage groups and control group. In particular, there was a declining trend of mouse body weight in the CTX group during the 10-d treatment period (Figure 4A,B), which would be a dangerous signal in clinical chemotherapy. Thus, it was concluded that $\mathbf{2}$ and $\mathbf{1 1}$ have significant antitumor activity by reducing both tumor size and weight in vivo. It is worth noting that no difference in mouse body weight was observed between the treatment groups and the blank control group, suggesting that the isocorydine derivatives had no adverse side effects on mouse growth as observed in 
the CTX group. Therefore, 8-acetamino-isocorydine (11) should be further investigated as a potential antitumor agent.

Table 3. Inhibitory effect of 8-acetamino-isocorydine (11) on $\mathrm{H}_{22}$-bearing mice.

\begin{tabular}{ccccc}
\hline $\begin{array}{c}\text { Treatment } \\
\text { group }\end{array}$ & $\begin{array}{c}\text { Mice } \\
\text { number }\end{array}$ & Dose $(\mathbf{m g} / \mathbf{k g} / \mathbf{d})$ & $\begin{array}{c}\text { Tumor weight } \\
(\mathbf{g}, \text { Mean } \pm \text { SD) }\end{array}$ & $\begin{array}{c}\text { Inhibition ratio } \\
(\%)\end{array}$ \\
\hline Control & 11 & - & $1.2189 \pm 0.5520$ & - \\
11 & 11 & 200 & $0.5764 \pm 0.2615 * *$ & 52.71 \\
11 & 11 & 100 & $0.5714 \pm 0.2087 * *$ & 53.12 \\
11 & 11 & 50 & $0.7359 \pm 0.4401 *$ & 39.63 \\
CTX & 11 & 20 & $0.2902 \pm 0.1610 * *$ & 76.19 \\
\hline
\end{tabular}

$v s$. the control group: $* p<0.05, * * p<0.01$.

Figure 3. Inhibitory effect of 8-acetamino-isocorydine (11) on murine hepatoma $\mathrm{H}_{22}$-bearing mice. (A) Photograph of the tumors excised from H22-bearing mice (a, blank control group; b, $50 \mathrm{mg} / \mathrm{kg}$ group; c, $100 \mathrm{mg} / \mathrm{kg}$ group; d, $200 \mathrm{mg} / \mathrm{kg}$ group; e, CTX group). From the perspective of gross anatomy, the tumor size of treatment groups and the CTX group were all significantly different from that of the control group; (B) The mean tumor weights $(\mathrm{X}+\mathrm{SD})$ of all groups. The tumor weights of the high dosage group, the medium dosage group and the CTX group were all significantly different from that of the blank control group $(* * p<0.01, * p<0.05)$.

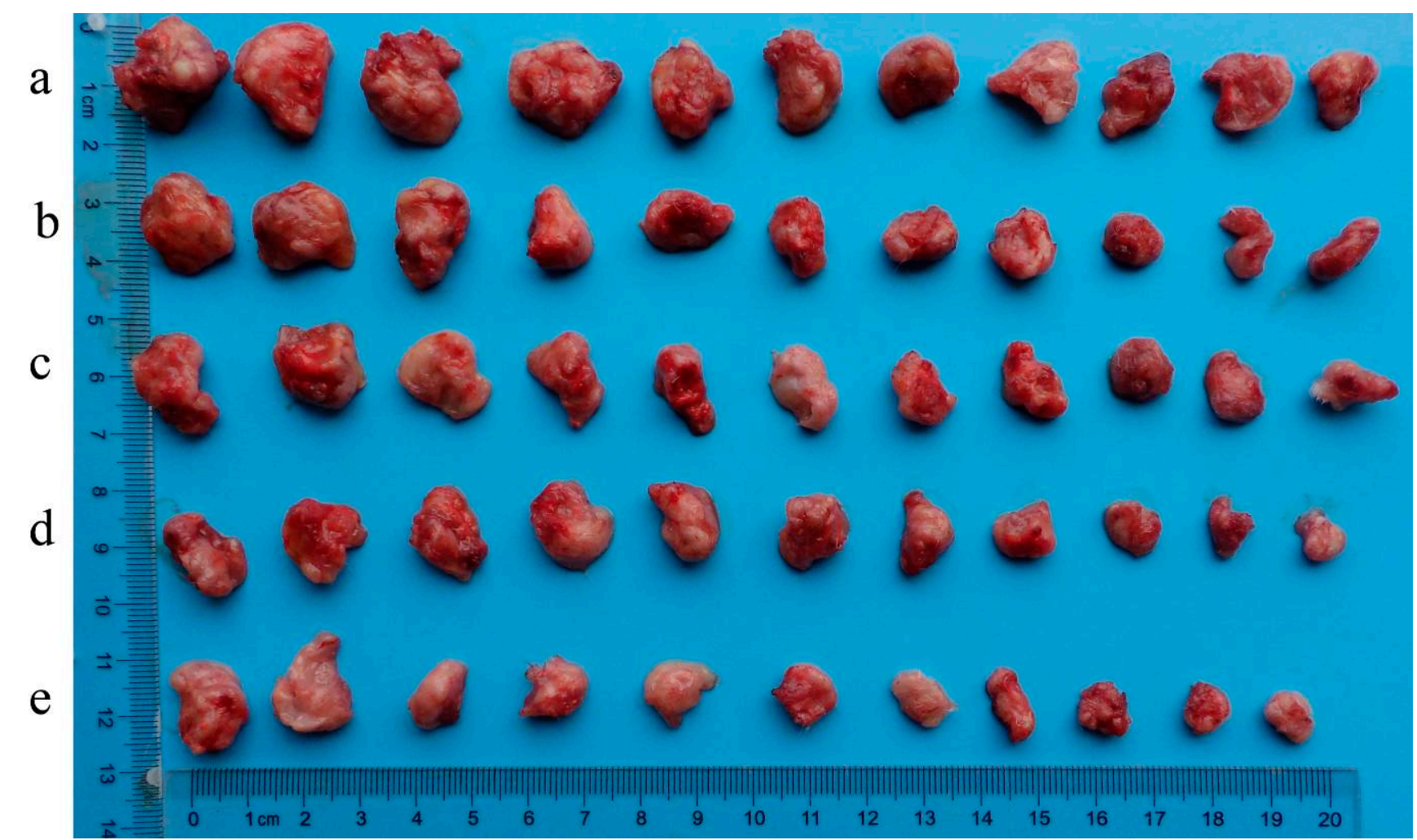

(A) 
Figure 3. Cont.

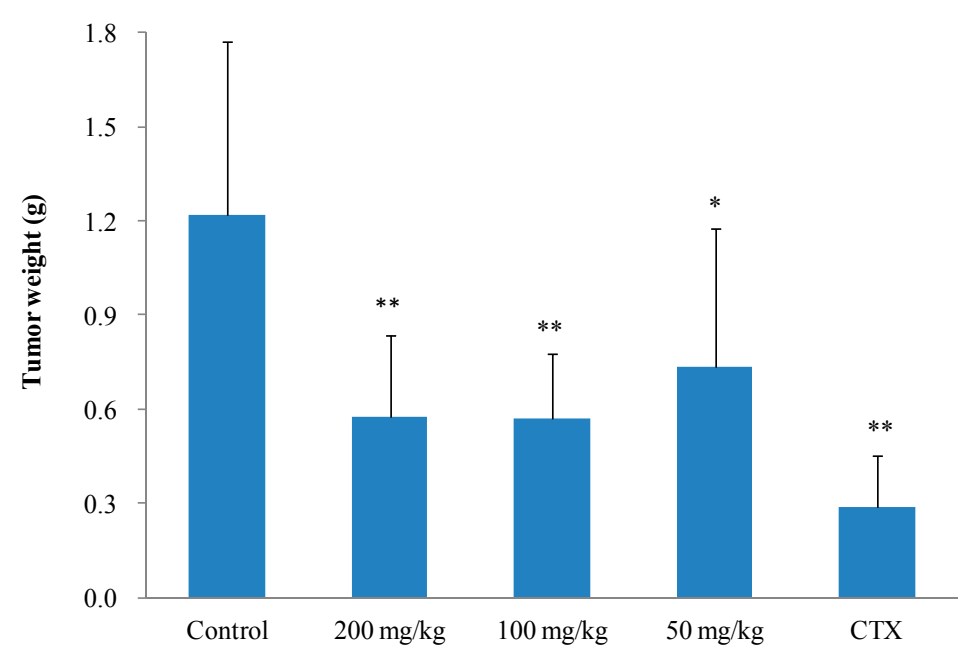

(B)

Figure 4. Influence of 8-acetamino-isocorydine (11) on body weight of mice bearing murine hepatoma $\mathrm{H}_{22}$. (A) The trend of weight increase during the treatment period with 11. The body weights increased in the blank control and treatment groups, but decreased in the CTX group; (B) Body weight of all groups at $10 \mathrm{~d}$. The body weight of the blank control group and treatment groups were significantly different from that of the CTX group $(* p<0.05)$. There was no significant difference between the blank control group and treatment groups.

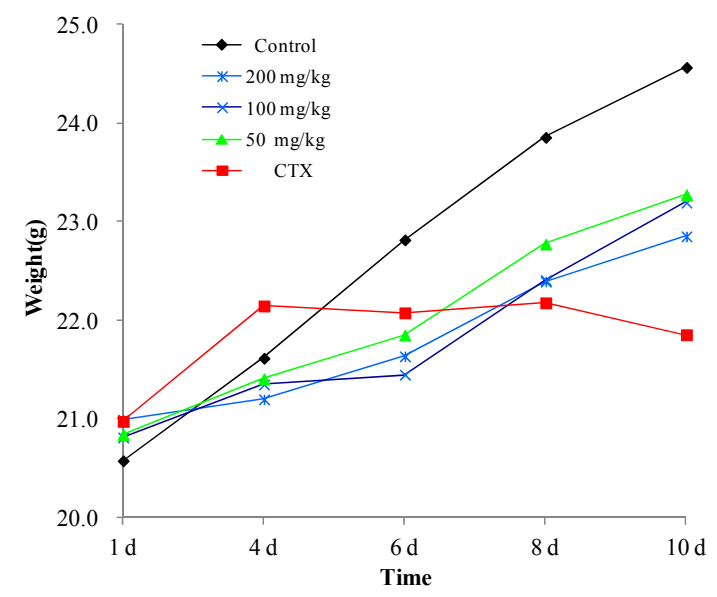

(A)

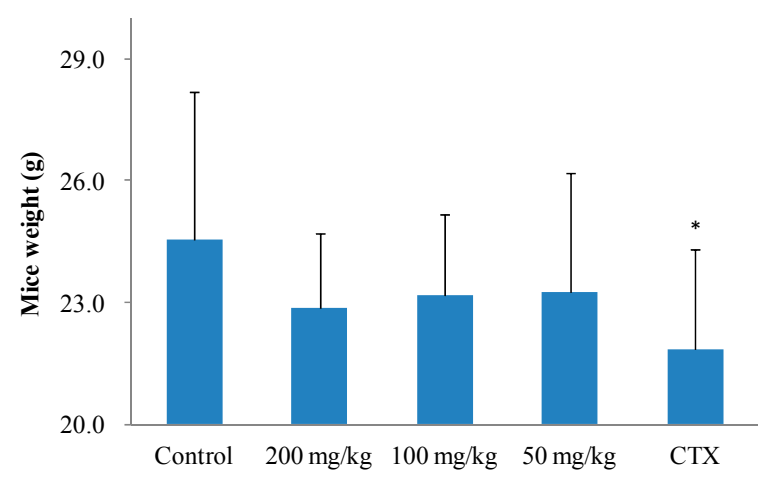

(B)

\subsection{The Structure and Activity Relationships of ICD Alkaloid}

In this research, the structure activity shows that different substituents at C-8 position can significantly affect the anticancer activities on test cell lines. That is, compounds that have strong electro donating group $\left(-\mathrm{NH}_{2}\right)$ at the $\mathrm{C}-8$ position have better in vitro anticancer activity than that of those that have electro withdrawing groups $\left(-\mathrm{NO}_{2}\right)$ and weak electro donating groups $(-\mathrm{Cl})$ at the C-8 position. 
The anticancer activity of $\mathbf{2}$ was superior to that of isocorydine (1), due to the p-benzoquinone fragment in its D ring, which could expand the conjugated system. As a biphenyl, isocorydine has a nearly coplanar and hyperconjugated rigid chemical skeleton, and its conjugated structure would be favorable to enhance the planarity of a targeted molecule, which could easily be intercalated into the DNA double helix and block DNA replication, thereby inhibiting cancer cell growth, which has been confirmed in the literature (Figure 1) [17,18]. However, although the chemical structure planarity of $\mathbf{2}$ was superior to that of 10, 2 showed weaker anticancer activity compared to $\mathbf{1 0}$ in vitro. This was likely due to the dehydrogenation reaction between C-6a and C-7 in 2 and not 10, which resulted in loss of the hydrogen atom at C-6a that affected the absolute configuration. Thus, the absolute configuration of the hydrogen atom at C-6a appears to be a key factor in the anticancer activity of these aporphine alkaloids, because the orientation of the hydrogen atom at C-6a determines the orientation of the lone pair of electrons of the nitrogen atom.

\section{Experimental}

\subsection{Chemistry}

\subsubsection{Materials}

Melting points were obtained on an X-4 digital display micro-melting point apparatus and uncorrected. NMR spectra were recorded on a Varian INOVA-400 MHz-FTNMR spectrometer with TMS as the internal standard. HRMS (ESI) was recorded on a Bruker APEX II. The HPLC system was an Agilent 1100 series with an autosampler and column heater (Palo Alto, CA, USA). The MS system was an Agilent LC-MSD-Trap (Palo Alto, CA, USA). An accurate post-column splitter from LC Packing (San Francisco, CA, USA) was used between the outlet of the UV detector and the inlet of the MS detector. Agilent MSD Trap control software version 5.0 (Palo Alto, CA, USA) was used for MS data acquisition and data processing. Chromatographic conditions for HPLC-UV-MS methods: UV detector settled at $270 \mathrm{~nm}$, a SinoCrom ODS-BP C18 column $(4.6 \mathrm{~mm} \times 250 \mathrm{~mm}, 5 \mu \mathrm{m})$ was used with the mobile phase consisting of $\mathrm{MeOH}$ :water (65:35, using aqua ammonia adjusted $\mathrm{pH}$ at 7.2 ) at a flow rate of $1.0 \mathrm{~mL} / \mathrm{min}$. The column temperature was maintained at $25{ }^{\circ} \mathrm{C}$. The sample solution was injected at a concentration of approximately $0.3 \mathrm{mg} / \mathrm{mL}$ with an injection volume of $20 \mu \mathrm{L}$. MS detection using ESI, operated in positive mode, was used to help identify molecular ions and track unknown degradation. The trap drive was set at $69 \mathrm{~V}$, drying temperature at $325{ }^{\circ} \mathrm{C}$, nebulizer gas at 8.0 psi, drying gas flow at $5.00 \mathrm{~L} / \mathrm{min}$, scan speed at $\mathrm{m} / z 13,000 \mathrm{~s}^{-1}$ and scan range $(\mathrm{m} / \mathrm{z})$ at $50-2200$.

Column chromatography was performed on silica gel (200-300 mesh, Qingdao Puke Parting Materials Co., Ltd., Qingdao, China). TLC was carried out on silica gel GF254 (Qingdao Marine Chemical Ltd., Qingdao, China), and spots were visualized under UV light or by spraying Dragendorff's reagent (Beijing, China). The $\mathrm{Pd} / \mathrm{C}(10 \%)$ catalyst was purchased from Sinopharm Chemical Reagent Co., Ltd (Shanghai, China).

The whole plants of D. leptopodum (Maxim) Fedde were collected in Pingliang of Gansu Province, China and identified by Prof. Zhigang Ma (Lanzhou University). A voucher specimen had been deposited at Key Laboratory of Chemistry of Northwestern Plant Resources and Key Laboratory for Natural Medicine of Gansu Province, Lanzhou Institute of Chemical Physics, Chinese Academy of Sciences, Lanzhou, China. 


\subsection{General Procedure for ICD Derivatives Preparations}

\subsubsection{Isolation of ICD (1)}

Whole plants of D. leptopodum (Maxim) Fedde $(200 \mathrm{~kg}$ ) were smashed and extracted twice with $95 \%$ ethanol $(1000 \mathrm{~L})$ at $60{ }^{\circ} \mathrm{C}$ for $2.5 \mathrm{~h}$. The mixture was filtered. The filtrate was combined and evaporated by a rotary evaporator. The residue $(24.0 \mathrm{~kg})$ was dissolved in $2 \% \mathrm{H}_{2} \mathrm{SO}_{4}$ aqueous solution $(200 \mathrm{~L})$. The solution was extracted with chloroform $(200 \mathrm{~L} \times 3)$. The chloroform parts were concentrated by a rotary evaporator and dried by a vacuum oven at $30{ }^{\circ} \mathrm{C}$ to give Extract $\mathrm{A}(5.0 \mathrm{~kg})$. The $\mathrm{pH}$ of the aqueous solution layer was adjusted with $\mathrm{NH}_{4} \mathrm{OH}$ to $\mathbf{9}$, and this solution was also extracted with chloroform to give Extract B $(2.0 \mathrm{~kg})$. Extract B was separated by silica gel column $(200 \mathrm{~cm} \times 2 \mathrm{~m})$ and was gradient eluted with chloroform $/ \mathrm{MeOH} /(\mathrm{Et})_{2} \mathrm{NH}(10: 1: 0.1$ to 2:1:0.1). Four fractions, $\mathrm{B}_{1}(400 \mathrm{~g}, 100: 1), \mathrm{B}_{2}(900 \mathrm{~g}, 50: 1), \mathrm{B}_{3}(500 \mathrm{~g}, 25: 1)$ and $\mathrm{B}_{4}(200 \mathrm{~g}, 5: 1)$, were obtained. Then, $B_{2}$ was further separated by silica gel column to give ICD (1) $250.0 \mathrm{~g}$, which has been recrystallized from methanol to obtain colorless prism crystal. M.p.: $185-186{ }^{\circ} \mathrm{C} ;[\alpha]_{\mathrm{D}}^{24}+205.0(\mathrm{c} 0.1$, $\mathrm{MeOH}) ;{ }^{1} \mathrm{H}-\mathrm{NMR}\left(400 \mathrm{MHz}, \mathrm{CD}_{3} \mathrm{COCD}_{3}\right) \delta: 6.74$ (1H, s, H-3), 3.36 (2H, m, H-4), 2.49 (2H, m, H-5), $2.61(1 \mathrm{H}, \mathrm{dd}, J=16.4,3.6 \mathrm{~Hz}, \mathrm{H}-6 \mathrm{a}), 2.99(2 \mathrm{H}, \mathrm{m}, \mathrm{H}-7), 7.00(1 \mathrm{H}, \mathrm{d}, J=8.0 \mathrm{~Hz}, \mathrm{H}-8), 7.14$ $(1 \mathrm{H}, \mathrm{d}, J=8.0 \mathrm{~Hz}, \mathrm{H}-9), 3.04\left(3 \mathrm{H}, \mathrm{s}, \mathrm{N}-\mathrm{CH}_{3}\right), 3.67\left(3 \mathrm{H}, \mathrm{s}, 1-\mathrm{OCH}_{3}\right), 3.88\left(3 \mathrm{H}, \mathrm{s}, 2-\mathrm{OCH}_{3}\right), 3.79(3 \mathrm{H}, \mathrm{s}$, 10- $\left.\mathrm{OCH}_{3}\right) ;{ }^{13} \mathrm{C}-\mathrm{NMR}\left(100 \mathrm{MHz}, \mathrm{CD}_{3} \mathrm{COCD}_{3}\right) \delta: 142.5$ (C-1), 124.2 (C-1a), 126.2 (C-1b), $152.0(\mathrm{C}-2)$, 111.4 (C-3), 130.7 (C-3a), 35.9 (C-4), 52.7 (C-5), 63.0 (C-6a), 29.5 (C-7), 128.6 (C-7a), 119.4 (C-8), 112.1 (C-9), 149.1 (C-10), 144.1 (C-11), $124.3(\mathrm{C}-11 \mathrm{a}), 65.5\left(1-\mathrm{OCH}_{3}\right), 55.4\left(2-\mathrm{OCH}_{3}\right), 52.7\left(10-\mathrm{OCH}_{3}\right)$, $43.4\left(\mathrm{~N}-\mathrm{CH}_{3}\right)$. HRMS (ESI): $m / z$ calcd. for $\mathrm{C}_{20} \mathrm{H}_{24} \mathrm{NO}_{4}[\mathrm{M}+\mathrm{H}]^{+}$342.1699, obsd. 342.1647 .

\subsubsection{Synthesis of Isocorydione (2)}

Compound 2 was synthesized from isocorydine by using a method described previously [15]. Chopped ice $(200.0 \mathrm{~g})$ was added to a solution of sodium nitrite $(5 \mathrm{M}, 100 \mathrm{~mL})$ at $0{ }^{\circ} \mathrm{C}$. The solution was stirred steadily while adding fresh sodium bisulfate solution $(100 \mathrm{~mL}, 35 \% \mathrm{w} / \mathrm{v})$, followed by glacial acetic acid $(20 \mathrm{~mL})$. After stirring for 2-3 min, the color of the reaction mixture became dark, and concentrated ammonia solution $(25 \mathrm{~mL})$ was added. Subsequently, ice-cold potassium permanganate solution $(0.2 \mathrm{M}, 400 \mathrm{~mL})$ was added in a drop-wise manner over $1 \mathrm{~h}$. When the color of the reaction mixture became dark brown, the reaction was terminated. Manganese dioxide, which was generated in the reaction, was filtered rapidly. A portion of the filtrate $(10-15 \mathrm{~mL})$ was treated with an equal volume of saturated potassium chloride solution to prepare Fremy salt as a seed crystal. Saturated potassium chloride solution $(250 \mathrm{~mL})$ was added in a drop-wise manner to the remaining filtrate over a period of approximately $45 \mathrm{~min}$. Subsequently, the previously prepared Fremy salt was added to the solution periodically until a solid appeared in the bulk solution. Then, the bulk solution was stirred in an ice bath for a further $45 \mathrm{~min}$. The orange solid (Fremy salt) was collected under vacuum filtration, and the solid was washed with an ammoniacal saturated potassium chloride solution (containing $\sim 5 \% \mathrm{v} / \mathrm{v} 0.88$ ammonium hydroxide), then with ammoniacal methanol (containing $\sim 5 \% \mathrm{v} / \mathrm{v} 0.88$ ammonium hydroxide) and, finally, with acetone.

To a solution of disodium hydrogen phosphate $(2.5 \mathrm{~g})$ in water $(750 \mathrm{~mL})$, Fremy radical $(12.0 \mathrm{~g})$ was added followed by 1 (5.0 g). The reaction mixture was stirred overnight at room temperature. 
Then, the reaction solution was extracted with chloroform $(200 \mathrm{~mL} \times 3)$. The chloroform layers were combined, dried with $\mathrm{Na}_{2} \mathrm{SO}_{4}$ and evaporated by rotary evaporation under reduced pressure. The residue was purified through column chromatography on a silica gel (petroleum ether $\left(60-90{ }^{\circ} \mathrm{C}\right)$ : acetone, 3:1) to give isocorydione (2) (2.4 g, yield of 50\%). Compounds $\mathbf{3}, \mathbf{4}$ and $\mathbf{5}$ were by-products obtained during the synthesis of $\mathbf{2}$ and were also isolated from the chloroform residue through column chromatography, with yields of $1.0 \%, 2.0 \%$ and $5.0 \%$, respectively. Compound 2 is a purple amorphous powder (carbinol); purity: $98.0 \%$; solubility: soluble in organic solvent and insoluble in water; m.p.: $198-200{ }^{\circ} \mathrm{C}$; ${ }^{1} \mathrm{H}-\mathrm{NMR}\left(400 \mathrm{MHz}, \mathrm{CDCl}_{3}\right)$ : 6.93 (1H, s, H-3), 3.13 (2H, t, J=6.4 Hz, H-4), $3.47(2 \mathrm{H}, \mathrm{t}, J=6.4 \mathrm{~Hz}, \mathrm{H}-5), 6.95(1 \mathrm{H}, \mathrm{s}, \mathrm{H}-7), 5.90(1 \mathrm{H}, \mathrm{s}, \mathrm{H}-9), 3.17\left(3 \mathrm{H}, \mathrm{s}, \mathrm{N}-\mathrm{CH}_{3}\right), 3.97(3 \mathrm{H}, \mathrm{s}$, 1- $\left.\mathrm{OCH}_{3}\right), 3.87\left(3 \mathrm{H}, \mathrm{s}, 2-\mathrm{OCH}_{3}\right), 3.94\left(3 \mathrm{H}, \mathrm{s}, 10-\mathrm{OCH}_{3}\right) ;{ }^{13} \mathrm{C}-\mathrm{NMR}\left(100 \mathrm{MHz}, \mathrm{CDCl}_{3}\right): 143.8(\mathrm{C}-1)$, 126.9 (C-1a), 119.3 (C-1b), 152.2 (C-2), 112.8 (C-3), 128.3 (C-3a), 29.2 (C-4), 50.2 (C-5), 150.3 (C-6a), 98.3 (C-7), 136.5 (C-7a), 186.5 (C-8), 105.1 (C-9), 163.8 (C-10), 178.3 (C-11), 117.9 (C-11a), 60.7 $\left(1-\mathrm{OCH}_{3}\right), 56.5\left(2-\mathrm{OCH}_{3}\right), 56.4\left(10-\mathrm{OCH}_{3}\right), 40.2\left(\mathrm{~N}-\mathrm{CH}_{3}\right)$. HRMS (ESI): $\mathrm{m} / z$ calcd. for $\mathrm{C}_{20} \mathrm{H}_{20} \mathrm{NO}_{5}$ $[\mathrm{M}+\mathrm{H}]^{+} 354.1336$, obsd. 354.1335.

\subsubsection{4-Hydroxy-isocorydione (3)}

Purple amorphous powder (carbinol); purity: 95.0\%; solubility: soluble in organic solvent and insoluble in water; ${ }^{1} \mathrm{H}-\mathrm{NMR}\left(400 \mathrm{MHz}, \mathrm{CDCl}_{3}\right): 6.93(1 \mathrm{H}, \mathrm{s}, \mathrm{H}-3), 4.92(2 \mathrm{H}, \mathrm{t}, J=6.4,2.1 \mathrm{~Hz}, \mathrm{H}-4)$, $3.62(2 \mathrm{H}, \mathrm{t}, J=6.4 \mathrm{~Hz}, \mathrm{H}-5), 7.18(1 \mathrm{H}, \mathrm{s}, \mathrm{H}-7), 5.84(1 \mathrm{H}, \mathrm{s}, \mathrm{H}-9), 3.19\left(3 \mathrm{H}, \mathrm{s}, \mathrm{N}-\mathrm{CH}_{3}\right), 3.94(3 \mathrm{H}, \mathrm{s}$, 1- $\left.\mathrm{OCH}_{3}\right), 3.87\left(3 \mathrm{H}, \mathrm{s}, 2-\mathrm{OCH}_{3}\right), 3.85\left(3 \mathrm{H}, \mathrm{s}, 10-\mathrm{OCH}_{3}\right) ;{ }^{13} \mathrm{C}-\mathrm{NMR}\left(100 \mathrm{MHz}, \mathrm{CDCl}_{3}\right): 145.0(\mathrm{C}-1)$, 126.6 (C-1a), 119.1 (C-1b), 152.2 (C-2), 112.7 (C-3), 129.9 (C-3a), 66.6 (C-4), 57.1 (C-5), 149.1 (C-6a), 98.8 (C-7), 136.2 (C-7a), 186.1 (C-8), 105.2 (C-9), 163.8 (C-10), 178.5 (C-11), 118.0 (C-11a), 60.7 $\left(1-\mathrm{OCH}_{3}\right), 56.3\left(2-\mathrm{OCH}_{3}\right), 56.1\left(10-\mathrm{OCH}_{3}\right), 40.2\left(\mathrm{~N}-\mathrm{CH}_{3}\right)$. HRMS (ESI): $m / z$ calcd. for $\mathrm{C}_{20} \mathrm{H}_{20} \mathrm{NO}_{6}$ $[\mathrm{M}+\mathrm{H}]^{+} 370.1285$, obsd. 370.1289 .

\subsubsection{N-demethyl-isocorydione (4)}

Purple amorphous powder (carbinol); purity: 95.0\%; solubility: soluble in organic solvent and insoluble in water; ${ }^{1} \mathrm{H}-\mathrm{NMR}\left(400 \mathrm{MHz}, \mathrm{CDCl}_{3}\right): 6.95(1 \mathrm{H}, \mathrm{s}, \mathrm{H}-3), 3.13(2 \mathrm{H}, \mathrm{t}, J=6.4 \mathrm{~Hz}, \mathrm{H}-4), 3.55$ $(2 \mathrm{H}, \mathrm{t}, J=6.4 \mathrm{~Hz}, \mathrm{H}-5), 6.98(1 \mathrm{H}, \mathrm{s}, \mathrm{H}-7), 5.89(1 \mathrm{H}, \mathrm{s}, \mathrm{H}-9), 3.98\left(3 \mathrm{H}, \mathrm{s}, 1-\mathrm{OCH}_{3}\right), 3.88\left(3 \mathrm{H}, \mathrm{s}, 2-\mathrm{OCH}_{3}\right)$, $3.96\left(3 \mathrm{H}, \mathrm{s}, 10-\mathrm{OCH}_{3}\right) ;{ }^{13} \mathrm{C}-\mathrm{NMR}\left(100 \mathrm{MHz} \mathrm{CDCl}_{3}\right)$ : 143.9 (C-1), 126.7 (C-1a), 118.5 (C-1b), 152.6 (C-2), 113.3 (C-3), 128.7 (C-3a), 29.2 (C-4), 40.7 (C-5), 149.5 (C-6a), 100.7 (C-7), 136.5 (C-7a), 186.1 (C-8), 105.2 (C-9), 164.0 (C-10), 178.4 (C-11), 118.0 (C-11a), 60.7 (1-OCH $), 56.5$ (2-OCH $), 56.4$ (10-OCH $)$. HRMS (ESI): $m / z$ calcd. for $\mathrm{C}_{19} \mathrm{H}_{18} \mathrm{NO}_{5}[\mathrm{M}+\mathrm{H}]^{+} 340.1179$, obsd. 340.1183.

\subsubsection{7-Hydroxy-N-demethyl-isocorydione (5)}

Red amorphous powder, purity: 95.0\%; solubility: soluble in organic solvent and insoluble in water; ${ }^{1} \mathrm{H}-\mathrm{NMR}\left(400 \mathrm{MHz}, \mathrm{CDCl}_{3}\right): 7.21(1 \mathrm{H}, \mathrm{s}, \mathrm{H}-3), 7.73(1 \mathrm{H}, \mathrm{d}, J=5.2 \mathrm{~Hz}, \mathrm{H}-4), 8.83(1 \mathrm{H}, \mathrm{d}$, $J=5.2 \mathrm{~Hz}, \mathrm{H}-5), 6.67(1 \mathrm{H}, \mathrm{s}, \mathrm{H}-9), 4.07\left(3 \mathrm{H}, \mathrm{s}, 1-\mathrm{OCH}_{3}\right), 3.84\left(3 \mathrm{H}, \mathrm{s}, 2-\mathrm{OCH}_{3}\right), 4.01(3 \mathrm{H}, \mathrm{s}$, 10- $\left.\mathrm{OCH}_{3}\right) ;{ }^{13} \mathrm{C}-\mathrm{NMR}\left(100 \mathrm{MHz}, \mathrm{CDCl}_{3}\right): 146.2(\mathrm{C}-1), 117.3$ (C-1a), 121.8 (C-1b), 155.8 (C-2), 105.9 (C-3), 135.6 (C-3a), 122.7 (C-4), 145.4 (C-5), 145.3 (C-6a), 163.3 (C-7), 109.4(C-7a), 184.2 (C-8), 
101.5 (C-9), 159.1 (C-10), 138.8 (C-11),120.6 (C-11a), $63.2\left(1-\mathrm{OCH}_{3}\right), 56.6\left(2-\mathrm{OCH}_{3}\right), 56.4\left(10-\mathrm{OCH}_{3}\right)$. HRMS (ESI): $m / z$ calcd. for $\mathrm{C}_{19} \mathrm{H}_{17} \mathrm{NO}_{6}[\mathrm{M}+\mathrm{H}]^{+}$354.0972, obsd. 354.0976.

\subsubsection{8-Hydroxylamine-isocorydione (6)}

To a solution of $2(1.0 \mathrm{~g})$ in absolute ethyl alcohol $(150 \mathrm{~mL})$, sodium hydroxide $(1.3 \mathrm{~g})$ was added followed by hydroxyl ammonium chloride $(3.2 \mathrm{~g})$. The reaction mixture was refluxed at $80{ }^{\circ} \mathrm{C}$ for $1.5 \mathrm{~h}$. Then, the solvent was evaporated by rotary evaporation under reduced pressure. The crude product was purified by column chromatography on a silica gel (chloroform: methanol, 10:1) to give 8-hydroxylamine-isocorydione (6) with a yield of 90\%. Compound 6 is a brown crystal, purity: 99.0\%; solubility: soluble in organic solvent and slightly soluble in water; ${ }^{1} \mathrm{H}-\mathrm{NMR}$ (400 MHz, DMSO- $d_{6}$ ): $6.80(1 \mathrm{H}, \mathrm{s}, \mathrm{H}-3), 3.14$ (2H, t, H-4), 3.47 (2H, t, H-5), $7.18(1 \mathrm{H}, \mathrm{s}, \mathrm{H}-9), 3.16\left(3 \mathrm{H}, \mathrm{s}, \mathrm{N}-\mathrm{CH}_{3}\right), 3.90$ $\left(3 \mathrm{H}, \mathrm{s}, 1-\mathrm{OCH}_{3}\right), 3.73\left(3 \mathrm{H}, \mathrm{s}, 2-\mathrm{OCH}_{3}\right), 3.91\left(3 \mathrm{H}, \mathrm{s}, 10-\mathrm{OCH}_{3}\right), 11.90(1 \mathrm{H}, \mathrm{s},-\mathrm{OH}) ;{ }^{13} \mathrm{C}-\mathrm{NMR}$ (100 MHz, DMSO- $\left.d_{6}\right)$ : 142.7 (C-1), 126.5 (C-1a), 119.3 (C-1b), 151.3 (C-2), 112.1 (C-3), 128.7 (C-3a), 28.6 (C-4), 49.5 (C-5), 139.1 (C-6a), 147.8 (C-7a), 148.9 (C-8), 94.1 (C-9), 150.3 (C-10), 179.8 (C-11), 118.1 (C-11a), $59.4\left(1-\mathrm{OCH}_{3}\right), 56.2\left(2-\mathrm{OCH}_{3}\right), 40.1\left(10-\mathrm{OCH}_{3}\right), 39.9\left(\mathrm{~N}_{-} \mathrm{CH}_{3}\right)$. HRMS (ESI): $m / z$ calcd. for $\mathrm{C}_{20} \mathrm{H}_{22} \mathrm{~N}_{2} \mathrm{O}_{5}[\mathrm{M}+2 \mathrm{H}]^{+} 370.1397$, obsd. 370.1398 .

\subsubsection{Synthesis of 8-Nitro-isocorydine (7)}

A solution of isocorydine $(3.0 \mathrm{~g})$ in dichloromethane $(200 \mathrm{~mL})$ was treated with a nitration reagent, which was composed of fuming nitric acid $(0.74 \mathrm{~mL})$ and concentrated sulfuric acid $(98 \%, 0.74 \mathrm{~mL})$ at $-30{ }^{\circ} \mathrm{C}$. After stirring for $40 \mathrm{~min}$, the reaction mixture was poured into ice water and alkalified to pH 8 with ammonia water, and the solution was extracted three times with chloroform. The chloroform part was concentrated by rotary evaporation under reduced pressure. The residue was purified by column chromatography on a silica gel (chloroform: methanol, 20:1) to give 8-nitro-isocorydine (7), with a yield of $51 \%$. Compound 7 is a yellow needle crystal, purity: $99.0 \%$; solubility: soluble in organic solvent and insoluble in water; $[\alpha]_{\mathrm{D}}^{24}+170.0$ (c $\left.0.1, \mathrm{MeOH}\right) ;{ }^{1} \mathrm{H}-\mathrm{NMR}\left(400 \mathrm{MHz}, \mathrm{CDCl}_{3}\right)$ : $6.76(1 \mathrm{H}, \mathrm{s}, \mathrm{H}-3), 3.00$ (1H, m, H-4), 2.40-2.48 (1H, $J=17.2,2.8 \mathrm{~Hz}, \mathrm{H}-4), 2.68-2.72$ (2H, dd, $J=17.2$, $2.8 \mathrm{~Hz}, \mathrm{H}-5), 3.67$ (1H, dd, $J=14.4,3.2 \mathrm{~Hz}, \mathrm{H}-6 \mathrm{a}), 3.00-3.21$ (2H, m, H-7), 7.52 (1H, s, H-9), 3.46 $\left(3 \mathrm{H}, \mathrm{s}, \mathrm{N}-\mathrm{CH}_{3}\right), 3.71\left(3 \mathrm{H}, \mathrm{s}, 1-\mathrm{OCH}_{3}\right), 3.96\left(3 \mathrm{H}, \mathrm{s}, 2-\mathrm{OCH}_{3}\right), 3.90\left(3 \mathrm{H}, \mathrm{s}, 10-\mathrm{OCH}_{3}\right) ;{ }^{13} \mathrm{C}-\mathrm{NMR}$ (100 MHz, $\mathrm{CDCl}_{3}$ ): 142.3 (C-1), 128.0 (C-1a), 130.2 (C-1b), 151.4 (C-2), 112.1 (C-3), 127.5 (C-3a), 29.1 (C-4), 52.6 (C-5), 62.4 (C-6a), 31.0 (C-7), 121.3 (C-7a), 141.8 (C-8), 107.1 (C-9), 148.8 (C-10), 148.7 (C-11), 123.8 (C-11a), $61.6\left(1-\mathrm{OCH}_{3}\right), 56.3\left(2-\mathrm{OCH}_{3}\right), 55.9\left(10-\mathrm{OCH}_{3}\right), 43.9\left(\mathrm{~N}-\mathrm{CH}_{3}\right) . \mathrm{HRMS}$ (ESI): $m / z$ calcd. for $\mathrm{C}_{20} \mathrm{H}_{23} \mathrm{~N}_{2} \mathrm{O}_{6}[\mathrm{M}+\mathrm{H}]^{+} 387.1551$, obsd. 387.1565 .

\subsubsection{8-Amino-isocorydine $(\mathbf{8})$}

The mixture of Compound $7(1.0 \mathrm{~g})$ with palladium on carbon hydrogenation catalyst $(10 \%, 0.5 \mathrm{~g})$ in absolute ethyl alcohol $(400 \mathrm{~mL})$ was stirred for $1.5 \mathrm{~h}$, with hydrogen pressure maintained at $0.3 \mathrm{MPa}$ in a high-pressure autoclave. Then, the mixture was filtered to remove the catalyst. The filtrate was evaporated by rotary evaporation under reduced pressure. The residue was purified by column chromatography on a silica gel (chloroform:methanol, 5:1) to give 8-amino-isocorydine (8), with a 
yield of $80 \%$, which is a brown amorphous powder; purity: $98.0 \%$; solubility: soluble in organic solvent and in water; $[\alpha]_{\mathrm{D}}^{24}+170.0(\mathrm{c} 0.1, \mathrm{MeOH}) ;{ }^{1} \mathrm{H}-\mathrm{NMR}\left(400 \mathrm{MHz}, \mathrm{CDCl}_{3}\right): 6.60(1 \mathrm{H}, \mathrm{s}, \mathrm{H}-3), 3.00$ (2H, m, H-4), 2.43 (2H, m, H-5), 3.00 (1H, m, H-6a), 2.88 (1H, dd, J = 16.4, $2.0 \mathrm{~Hz}, \mathrm{H}-7), 2.60$ (1H, dd, $J=16.4,2.0 \mathrm{~Hz}, \mathrm{H}-7), 4.35\left(2 \mathrm{H}, \mathrm{s}, 8-\mathrm{NH}_{2}\right), 6.34(1 \mathrm{H}, \mathrm{s}, \mathrm{H}-9), 2.51\left(3 \mathrm{H}, \mathrm{s}, \mathrm{N}-\mathrm{CH}_{3}\right), 3.56(3 \mathrm{H}, \mathrm{s}$, 1- $\left.\mathrm{OCH}_{3}\right), 3.79\left(3 \mathrm{H}, \mathrm{s}, 2-\mathrm{OCH}_{3}\right), 3.76\left(3 \mathrm{H}, \mathrm{s}, 10-\mathrm{OCH}_{3}\right) ;{ }^{13} \mathrm{C}-\mathrm{NMR}\left(100 \mathrm{MHz}, \mathrm{CDCl}_{3}\right): 142.2(\mathrm{C}-1)$, 125.9 (C-1a), 128.9 (C-1b), 151.2 (C-2), 113.0 (C-3), 127.6 (C-3a), 29.2 (C-4), 52.2 (C-5), 62.2 (C-6a), 36.6 (C-7), 120.6 (C-7a), 135.4 (C-8), 102.0 (C-9), 149.2 (C-10), 136.9 (C-11), 110.7 (C-11a), 62.8 $\left(1-\mathrm{OCH}_{3}\right), 55.8\left(2-\mathrm{OCH}_{3}\right), 55.4\left(10-\mathrm{OCH}_{3}\right), 43.9\left(\mathrm{~N}-\mathrm{CH}_{3}\right)$. HRMS (ESI): $m / z$ calcd. for $\mathrm{C}_{20} \mathrm{H}_{25} \mathrm{~N}_{2} \mathrm{O}_{4}$ $[\mathrm{M}+\mathrm{H}]^{+} 357.1809$, obsd. 357.1816.

\subsubsection{8-Chloro-isocorydine (9)}

$\mathrm{N}$-chlorosuccinimide $(1.2 \mathrm{~g})$ was added to a stirred solution of isocorydine $(3.0 \mathrm{~g})$ in glacial acetic acid $(150 \mathrm{~mL})$. After vigorous stirring for $2 \mathrm{~h}$ at $7{ }^{\circ} \mathrm{C}$, the reaction mixture was poured into ice, alkalified to $\mathrm{pH} 8$ with ammonia water and extracted three times with chloroform. The organic part was combined and evaporated by rotary evaporation under reduced pressure. The residue was purified by column chromatography on a silica gel (chloroform: methanol, 20:1) to give 8-chloro-isocorydine (9), with a yield of $60 \%$, which is a yellow amorphous powder. Purity: $98.0 \%$; solubility: soluble in organic solvent and insoluble in water; $[\alpha]_{\mathrm{D}}^{24}+175.0(\mathrm{c} 0.1, \mathrm{MeOH}){ }^{1} \mathrm{H}-\mathrm{NMR}\left(400 \mathrm{MHz}, \mathrm{CDCl}_{3}\right): 6.74$ (1H, s, H-3), 2.31-2.31 (2H, m, H-4), 2.91-2.95 (2H, m, H-5), 3.06 (1H, m, H-6a), 2.67-2.69 (2H, m, H-7), $7.50(1 \mathrm{H}, \mathrm{s}, \mathrm{H}-9), 2.38\left(3 \mathrm{H}, \mathrm{s}, \mathrm{N}-\mathrm{CH}_{3}\right), 3.60\left(3 \mathrm{H}, \mathrm{s}, 1-\mathrm{OCH}_{3}\right), 3.85\left(3 \mathrm{H}, \mathrm{s}, 2-\mathrm{OCH}_{3}\right), 3.79(3 \mathrm{H}, \mathrm{s}$, 10- $\left.\mathrm{OCH}_{3}\right) ;{ }^{13} \mathrm{C}-\mathrm{NMR}\left(100 \mathrm{MHz}, \mathrm{CDCl}_{3}\right): 142.1(\mathrm{C}-1), 128.5(\mathrm{C}-1 \mathrm{a}), 130.1(\mathrm{C}-1 \mathrm{~b}), 151.2(\mathrm{C}-2), 112.0$ (C-3), 127.4 (C-3a), 29.6 (C-4), 52.5 (C-5), 62.3 (C-6a), 30.9 (C-7), 121.2 (C-7a), 141.7 (C-8), 107.0 (C-9), 148.3 (C-10), 148.7 (C-11),123.7 (C-11a), $61.5\left(1-\mathrm{OCH}_{3}\right), 56.3\left(2-\mathrm{OCH}_{3}\right), 55.9\left(10-\mathrm{OCH}_{3}\right)$, $43.9\left(\mathrm{~N}-\mathrm{CH}_{3}\right)$. HRMS (ESI): $m / z$ calcd. for $\mathrm{C}_{20} \mathrm{H}_{22} \mathrm{NO}_{4} \mathrm{Cl}[\mathrm{M}]^{+}$375.1237, obsd. 375.2060.

\subsubsection{6a,7-Dihydrogen-isocorydione (10)}

Sodium nitrite $(1.3 \mathrm{~g})$ was added into the water $(250 \mathrm{~mL})$ solution of $8(3.4 \mathrm{~g})$ and then hydrochloric acid $(1.2 \mathrm{~mL})$ was dropped in the reaction bulb. The mixture was stirred for $1 \mathrm{~h}$ at $0{ }^{\circ} \mathrm{C}$. Then, the reaction was quenched by adding a solution of urea $(10 \%)$. The reaction solution was extracted with 1,2-dichloroethane $(200 \mathrm{~mL} \times 3)$. The organic layers were combined and evaporated by rotary evaporation. The crude product was then purified by column chromatography on a silica gel (chloroform: methanol, 20:1) to give 6a, 7-dihydrogen-isocorydione (10), with a yield of 20\%, which is a brown amorphous powder. Purity: $99.0 \%$; solubility: soluble in organic solvent and insoluble in water; ${ }^{1} \mathrm{H}-\mathrm{NMR}\left(400 \mathrm{MHz}, \mathrm{CDCl}_{3}\right): 6.67(1 \mathrm{H}, \mathrm{s}, \mathrm{H}-3), 5.88(1 \mathrm{H}, \mathrm{s}, \mathrm{H}-9), 3.84\left(3 \mathrm{H}, \mathrm{s}, 1-\mathrm{OCH}_{3}\right), 3.82$ $\left(3 \mathrm{H}, \mathrm{s}, 10-\mathrm{OCH}_{3}\right), 3.79\left(3 \mathrm{H}, \mathrm{s}, 2-\mathrm{OCH}_{3}\right), 2.46\left(3 \mathrm{H}, \mathrm{s}, \mathrm{N}-\mathrm{CH}_{3}\right), 3.34(1 \mathrm{H}, \mathrm{m}, \mathrm{H}-6 \mathrm{a}), 3.00(2 \mathrm{H}, \mathrm{m}, \mathrm{H}-5)$, $2.42(1 \mathrm{H}, \mathrm{m}, \mathrm{H}-4), 2.85(1 \mathrm{H}, \mathrm{dd}, J=16.4 \mathrm{~Hz}, \mathrm{H}-7), 2.60(1 \mathrm{H}, \mathrm{dd}, J=16.4 \mathrm{~Hz}, \mathrm{H}-7) ;{ }^{13} \mathrm{C}-\mathrm{NMR}$ (100 MHz, $\mathrm{CDCl}_{3}$ ): 140.8 (C-1), 127.9 (C-1a), 121.4 (C-1b), 151.8 (C-2), 114.3 (C-3), 128.4 (C-3a), 28.4 (C-4), 53.3 (C-5), 61.3 (C-6a), 25.6 (C-7), 185.5 (C-8), 106.1 (C-9), 160.1 (C-10), 180.2 (C-11), $127.8(\mathrm{C}-11 \mathrm{a}), 60.9\left(1-\mathrm{OCH}_{3}\right), 56.3\left(2-\mathrm{OCH}_{3}\right), 55.7\left(10-\mathrm{OCH}_{3}\right), 43.9\left(\mathrm{~N}_{-} \mathrm{CH}_{3}\right) . \mathrm{HRMS}(\mathrm{ESI}): \mathrm{m} / \mathrm{z}$ calcd. for $\mathrm{C}_{20} \mathrm{H}_{21} \mathrm{NO}_{5}[\mathrm{M}+\mathrm{H}]^{+}$357.1576, obsd. 357.1534 . 


\subsubsection{8-Acetamino-isocorydine (11)}

Ten milliliters fresh distilled acetyl chloride were added to a mixture of $\mathbf{8}(1.0 \mathrm{~g})$ and $10 \mathrm{~mL}$ acetic ether in a round-bottomed flask, under vigorous stirring, and then the mixture was stirred at room temperature for $2 \mathrm{~h}$. Then, the reaction mixture was concentrated in vacuo to obtain a purple solid. The solid was then purified by column chromatography on a silica gel (chloroform: methanol, 5:1) to give 8 -acetamino-isocorydine (11), with a yield of $80 \%$, which is a brown amorphous powder. Purity: 99.0\%; solubility: soluble in organic solvent and in water; $[\alpha]_{\mathrm{D}}^{24}+172.0$ (c $\left.0.1, \mathrm{MeOH}\right)$; ${ }^{1} \mathrm{H}-\mathrm{NMR}$ (400 MHz, CD $\left.{ }_{3} \mathrm{Cl}\right): 7.53$ (1H, s, H-3), 3.00 (2H, m, H-4), 2.43 (2H, m, H-5), 3.00 (1H, m, H-6 $\mathrm{a}_{\mathrm{a}}$ ), 2.88 (1H, dd, $J=16.4,2.0 \mathrm{~Hz}, \mathrm{H}-7), 2.60(1 \mathrm{H}, \mathrm{dd}, J=16.4,2.0 \mathrm{~Hz}, \mathrm{H}-7), 6.73$ (1H, s, H-9), 2.48 (3H, s, $\left.\mathrm{N}-\mathrm{CH}_{3}\right), 3.43\left(3 \mathrm{H}, \mathrm{s}, 1-\mathrm{OCH}_{3}\right), 3.90\left(3 \mathrm{H}, \mathrm{s}, 2-\mathrm{OCH}_{3}\right), 3.86\left(3 \mathrm{H}, \mathrm{s}, 10-\mathrm{OCH}_{3}\right) ; 2.22\left(3 \mathrm{H}, \mathrm{s}, \mathrm{COCH}_{3}\right)$. ${ }^{13} \mathrm{C}-\mathrm{NMR}\left(100 \mathrm{MHz}, \mathrm{CD}_{3} \mathrm{Cl}\right): 146.3$ (C-1), 128.0 (C-1a), 128.5 (C-1b), 151.9 (C-2), 113.2 (C-3), 126.4 (C-3a), 29.4 (C-4), 52.7 (C-5), 61.8 (C-6a), 31.0 (C-7), 122.3 (C-7a), 141.4 (C-8), 107.1 (C-9), 150.9 (C-10), 146.1 (C-11), 123.8 (C-11a), $61.3\left(1-\mathrm{OCH}_{3}\right), 56.1\left(2-\mathrm{OCH}_{3}\right), 55.5\left(10-\mathrm{OCH}_{3}\right), 43.6$ $\left(\mathrm{N}-\mathrm{CH}_{3}\right), 21.1\left(\mathrm{COCH}_{3}\right)$. HRMS (ESI): $\mathrm{m} / z$ calcd. for $\mathrm{C}_{22} \mathrm{H}_{27} \mathrm{~N}_{2} \mathrm{O}_{5}[\mathrm{M}+\mathrm{H}]^{+}$399.1914, obsd. 399.1911.

\subsection{Biological Assay}

\subsubsection{Materials}

The human lung cancer cells (A549), human gastric cancer cells (SGC7901) and human liver cancer cells (HepG2) were provided by the Cell Bank of the Institute of Biochemistry and Cell Biology at the China Academy of Sciences (Shanghai, China). Murine sarcoma cell line $\mathrm{S}_{180}$ and murine hepatoma cell line $\mathrm{H}_{22}$ were obtained from cell library of Institute of Cancer Biology and Drug Discovery, Lanzhou University. All cell lines were cultured in RPMI 1640 medium supplemented with $10 \%$ heat-inactivated fetal bovine serum (FBS), streptomycin $(100 \mu \mathrm{g} / \mathrm{mL})$ and penicillin $(100 \mathrm{U} / \mathrm{mL})$ in a humidified atmosphere containing $5 \% \mathrm{CO}_{2}$ at $37^{\circ} \mathrm{C}$. Kunming male mice weighing $18.0-22.0 \mathrm{~g}$ were purchased from the Experimental Animal Center at Lanzhou University. The use and treatment of mice were in accordance with institutional guideline for Laboratory Animal Care.

\subsubsection{Anticancer Activity in Vitro}

Cell proliferation was analyzed by a colorimetric MTT assay. Cells were seeded in 96-well plates at a density of $5 \times 10^{3}$ cells/well in $100 \mu \mathrm{L}$ RPMI 1640 medium supplemented with $10 \%$ FBS. After $12 \mathrm{~h}$, cells were treated with different concentrations of selected compounds in complete medium, respectively, while the negative control was treated with complete RPMI 1640 medium only. After $48 \mathrm{~h}$, $20 \mu \mathrm{L} \mathrm{MTT}(5 \mathrm{mg} / \mathrm{mL})$ was added. After the plates were incubated at $37{ }^{\circ} \mathrm{C}$ for $4 \mathrm{~h}$, the supernatant was removed, and then, $150 \mu \mathrm{L}$ DMSO were added to each well. Absorbance was measured at $570 \mathrm{~nm}$ by a 96-well microplate reader (DNM-9602).

\subsubsection{Anticancer Activity in Vivo}

Zero-point-two milliliters of model mice ascites, including $2 \times 10^{7} \mathrm{~S}_{180}$ or $\mathrm{H}_{22}$ cells $/ \mathrm{mL}$, were injected into the right axilla of mice. From the second day after the implantation of cancer cells, 55 
tumor-bearing mice were grouped randomly into five groups as the following: the blank control group was treated by physiological saline $(0.9 \%)$, and the positive control group was treated with cyclophosphamide (CTX) at a dosage of $20 \mathrm{mg} / \mathrm{kg}$. Medicated groups were intragastrically administered with targeted compound at $50 \mathrm{mg} / \mathrm{kg}, 100 \mathrm{mg} / \mathrm{kg}$ and $200 \mathrm{mg} / \mathrm{kg}$, respectively. Subsequently, mice were treated daily for the following 10 days. Twenty four hours after the last drug administration, mice were executed, and their tumors were totally excised and accurately weighed. The anticancer activity of ICD derivatives in vivo were expressed as an inhibitory rate, which was calculated with the formula: ((mean tumor weight of control group - mean tumor weight of dose group) $/$ mean tumor weight of control group) $\times 100 \%$.

\section{Conclusions}

Ten ICD derivatives have been prepared through chemical structure modification, and their anticancer activities of the key derivatives have been investigated through in vitro and in vivo experiments. The results suggested that structural modifications could significantly improve the anticancer activity of ICD alkaloid and have lower side effects on body weight than that of CTX, which indicated that ICD can be a lead compound for the development of an effective anticancer agent.

\section{Supplementary Materials}

Supplementary materials can be accessed at: http://www.mdpi.com/1420-3049/19/8/12099/s1.

\section{Acknowledgments}

This work was supported by "West Light Program", "Build coalitions of the national academy of sciences" of Chinese Academy of Sciences and the science and technology program of Gansu (1304FKCA062).

\section{Author Contributions}

All authors contributed equally.

\section{Conflicts of Interest}

The authors declare no conflict of interest.

\section{References}

1. Liu, Y.J.; Liu, J.X.; Di, D.L.; Li, M.; Fen,Y. Structural and mechanistic bases of the anticancer activity of natural aporphinoid alkaloids. Curr. Top. Med. Chem. 2013, 13, 2116-2126.

2. Stévigny, C.; Bailly, C.; Quetin-Leclercq, J. Cytotoxic and antitumor potentialities of aporphinoid alkaloids. Curr. Med. Chem. Anticancer Agents 2005, 5, 173-182.

3. Gerhardt, D.; Horn, A.; Gaelzer, M.; Frozza, R.; Delgado-Canedo, A.; Pelegrini, A.; Henriques, A.; Lenz, G.; Salbego, C. Boldine: A potential new antiproliferative drug against glioma cell lines. Investig. New Drugs 2009, 27, 517-525. 
4. Zhang, A.; Zhang, Y.; Branfman, A.; Baldessarini, R.; Neumeyer, J. Advances in development of dopaminergic aporphinoids. J. Med. Chem. 2007, 50, 171-181.

5. Ponnala, S.; Chaudhary, S.; Gonzalez-sarrias, A.; Seeram, N.; Harding, W. Cytotoxicity of aporphines in human colon cancer cell lines HCT-116 and Caco-2: An SAR study. Bioorg. Med. Chem. Lett. 2011, 21, 4462-4464.

6. Guo, C.C.; Yu, C.H.; Li, L.; Wang, Y.Q.; Wang, S.J.; Wang, W.H.; Hu, H.H.; Xu, S.Y.; Yu, L.S.; Jiang, H.D.; et al. Rapid determination of isocorydine in rat plasma and tissues using liquid chromatography-Tandem mass spectrometry and its applications to pharmacokinetics and tissue distribution. Xenobiotica 2012, 42, 466-476.

7. Dang, Y.; Gong, H.F.; Liu, J.X.; Yu, S.J. Alkaloid from Dicranostigma leptopodum (Maxim) Fedde. Chin. Chem. Lett. 2009, 20, 1218-1220.

8. Liu, D.H.; Zhang, T.C.; Liu, J.X.; Di, D.L.; Dang, Y. Chemical constituents of alkaloids from Dicranostigma leptopodum. Chin. Tradit. Herb Drugs 2011, 42, 1505-1508.

9. Sun, H.F.; Hou, H.L.; Lu, P.; Zhang, L.X.; Zhao, F.Y.; Ge, C.; Wang, T.P.; Yao, M.; Li, J.J. Isocorydine inhibits cell proliferation in hepatocellular carcinoma cell lines by inducing G2/M cell cycle arrest and apoptosis. PLoS One 2012, 7, e36808.

10. Lu, P.; Sun, H.F.; Zhang, L.X.; Hou, H.L; Zhang, L.; Zhao, F.Y.; Ge, C.; Yao, M.; Wang, T.P.; $\mathrm{Li}$, J.J. Isocorydine targets the drug-resistant cellular side population through PDCD4-related apoptosis in hepatocellular carcinoma. Mol. Med. 2012, 18, 1136-1146.

11. Ma, S.; Lee, T.K.; Zheng, B.J.; Chan K.W.; Guan, X.Y. CD133 ${ }^{+}$HCC cancer stem cells confer chemoresistance by preferential expression of the Akt/PKB survival pathway. Oncogene 2008, 27, 1749-1758.

12. Ferreira, M.L.R.; Pascoli, I.C.; Nascimento, I.R.; Zukerman-Schpector, J.; Lopes, L.M.X. Aporphine and bisaporphine alkaloids from Aristolochia lagesiana var. intermedia. Photochemistry 2010, 71, 569-478.

13. Zhang, T.C.; Ye, H.L.; Liu, J.X.; Di, D.L. Study on semi-synthetic transforming technology for the natural product of isocorydione. Acta Pharm. Sin. 2011, 46, 1471-1475.

14. Chia, Y.C; Chang, F.R.; Wu, Y.C. Two p-Quinonoid aporphine alkaloids from Fissistigma balansae. J. Nat. Prod. 1998, 61, 1430-1432.

15. Mosmann, T. Rapid colorimetric assay for cellular growth and survival: Application to proliferation and cytotoxicity assays. J. Immunol. Methods 1983, 65, 55-63.

16. Wu, Z.Q.; Patel, A.; Dave, R.; Yuan, X.D. Development of acetaminophin proline prodrug. Bioorg. Med. Chem. Lett. 2010, 20, 3851-3854.

17. Woo, S.H.; Sun, N.J.; Cassady, J.M.; Snapka, R.M. Topoisomerase II inhibition by aporphine alkaloids. Biochem. Pharmacol. 1999, 57, 1141-1145.

18. Ribár, B.; Lazar, D.; Gašić, O.; Kanyó, I.; Engel, P. Structure of isocorydine. Acta Cryst. 1992, C48, 945-947.

Sample Availability: All products reported in this paper are available from the authors.

(C) 2014 by the authors; licensee MDPI, Basel, Switzerland. This article is an open access article distributed under the terms and conditions of the Creative Commons Attribution license (http://creativecommons.org/licenses/by/3.0/). 